\title{
STUDY OF CARBON SEQUESTRATION BY ROAD SIDE PLANTATION NEAR COIMMONWEALTH GAMMES VILLAGE
}

KEY WORDS: CWGV, AGB

Carbon Sequestration, Plantation

\section{Dr Prabha Kiran ACADEMICIAN}

Land use is changing to meet the requirement of urbanization. International effort is made to reduce atmospheric carbon. Plantation of trees is one of the way to fix the atmospheric carbon. Road side plantation can play a crucial role in carbon sequestration and also generate availability of land for the plantation. In the present study examination of carbon eㅏㄹ significant.

\section{Introduction:}

Land use is changing to meet the requirement of urbanization. This is causing environmental stress and problems. Climate change and Global Warming are internationally widely discussed issues. The effect of climate change have been observed across the globe. Reduction of carbon dioxide content in atmosphere is possible in two ways namely through emission cut and the other way is to increase the amount of carbon sequestered by terrestrial ecosystem. Trees plays crucial role in mitigation of such problems. Roadside plantation plays significant role in fixation of atmospheric carbon. The present study seeks to exemplify and bring out the potential of young road side plantation along a small stretch of minor road to fix substantial amount of carbon.

\section{Material and Methods}

To assess the fixation of atmospheric carbon by road side plantation along a minor road in front of Commonwealth Games Village residential complex in New Delhi was selected for the present study. Along the road on both side and on the central verge the planted trees of species Ficus benjamina, Mulberry (Morus alba), Sheesham (Dalbergia sissoo), Gulmohar, Ber etc. Total 397 trees of girth at breast height (GBH) more than $10 \mathrm{~cm}$ were observed. GBH of all these trees were measured. The trees were arranged according to the girth class. Based on the mean girth class ( mean GBH of the class) it was converted to mean diameter (DBH) for the class. Subsequently based on the DBH the estimation of the Above Ground Biomass (AGB) and Below Ground Biomass ( BGB ) was estimated using the empirical formulae given in the reference ( Carbon flow in Delhi, Urban Ecosystem, Tripathy and Joshi (2019)). The empirical formulae used for the estimation are:

Above Ground Biomass $($ AGB $)=34.4703-8.0671 \mathrm{D}+0.6589$ $\mathrm{D}^{2}$;

Below Ground Biomass (BGB) $=15 \%$ AGB;

Total Biomass $(\mathrm{TB})=\mathrm{AGB}+\mathrm{BGB}$.

Carbon content: $50 \%$ of the TB

The amount of carbon sequestered by each tree was estimated using the mean DBH for the corresponding GBH class. The Above Ground Biomass (AGB), Below Ground Biomass(BGB), Total Biomass (TB) and then Carbon sequestered was estimated.

The complete exercise for collection of primary data was done by non destructive method without felling of any tree in process. The rationale for the use of Carbon sequestered using the value of DBH is there in the reference by Tripathy and Joshi (2015).

\section{RESULTS AND DISCUSSION}

The Girth of the trees at Breast Height (GBH) for each trees above $10 \mathrm{~cm}$ was measured and tabulated in Table-1. To have table of reasonable size, the girth class of size $30 \mathrm{~cm}$ was decided and trees GBH for each of the girth class of different |www.worldwidejournals.com species were counted and tabulated accordingly.

Table-1 : Measurement of GBH of the trees and tabulation of observation

\begin{tabular}{|c|c|c|c|c|c|}
\hline $\begin{array}{c}\text { Girth } \\
\text { Class }\end{array}$ & $\begin{array}{c}\text { Ficus } \\
\text { In cm } \\
\text { (in no.) }\end{array}$ & $\begin{array}{c}\text { Gulmo } \\
\text { har } \\
\text { (in no) }\end{array}$ & $\begin{array}{c}\text { Sheesham } \\
\text { (in no) }\end{array}$ & $\begin{array}{c}\text { Other } \\
\text { Miscellaneo } \\
\text { us Species } \\
\text { (in No) }\end{array}$ & $\begin{array}{c}\text { Total } \\
\text { Trees (in } \\
\text { no) }\end{array}$ \\
\hline $10-30$ & 10 & 20 & 4 & 12 & 46 \\
\hline $31-60$ & 78 & 40 & 3 & 13 & 134 \\
\hline $61-90$ & 131 & 5 & - & 1 & 137 \\
\hline $91-120$ & 53 & - & 3 & - & 56 \\
\hline $121-150$ & 18 & - & - & - & 18 \\
\hline $150-180$ & 6 & - & - & - & 6 \\
\hline
\end{tabular}

Based on the data on GBH and no of trees collected and segregated as in Table-1, the calculation of Mean class DBH, Above Ground Biomass(AGB) , Below Ground Biomass (BGB), Total Biomass, Carbon Sequestered by the said trees were calculated and presented as in Table-2.

Table-2: Estimation of Carbon Sequestered by the trees

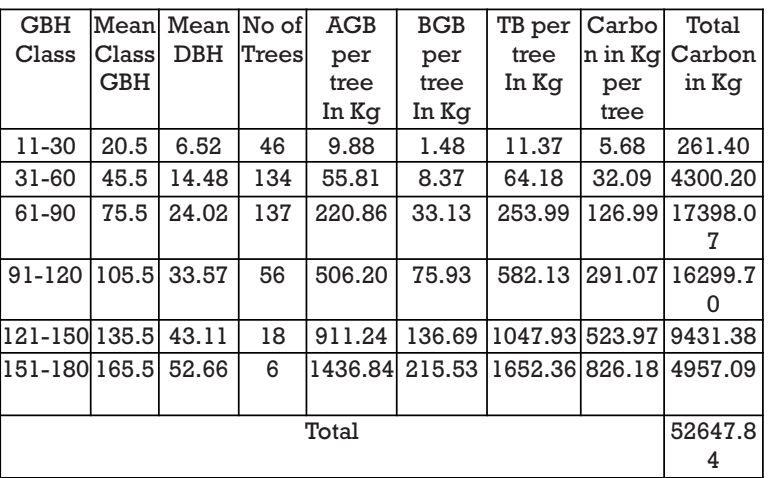

Its evident from above that even small no. of planted young trees i.e. 397 trees in present study of medium height and canopy on a small stretch of road may sequester approximately $52648 \mathrm{Kg}$ of atmospheric carbon. So it may be inferred that road side plantation plays important role in sequestering atmospheric carbon. These plantation help in international effort towards atmospheric climate change and to reduce the presence of $\mathrm{CO} 2$ in the air. Also in the present study for better understanding of the role of road side plantation in sequestering atmospheric carbon, the same empirical relation has been used for computational purpose but considering the fact that that species may have slight variation in carbon density within them, study could be extended further and species specific empirical relation may be used for ascertaining their carbon sequestration potential.

\section{REFERENCES}

1. Byrne J., Yang J., 2009. Can urban greenspace combat climate change? Towards a Subtropical cities research agenda. Australian Planner, 46(10.1080/07293682.20091075342036-43), pp.36-43.

2. Chaturvedi R.K., Ravindranath N.H.,2008. India Forest Sector-Current Trends 
and Future Challenges. Climate Change and Forest in India, The International Forestry Review, 10(2),pp. 256-268.

3. Choudhary P., Bagra K., Singh B., 2011 .Urban Greenery Status of Dome Indian Cities- A short commentary. International Journal of Environmental Science and Development, 2(2), pp. 1-4.

4. Pincell S., Gillespie T., Pataki D. E., Saatchi S., Saphores J. D., 2013. Urban Tree planting programme, function or fashion? Los Angeles and Urban tree planting campaign. GeoJournal, Issue 78, pp. 475-493.

5. Ravi A., 2008. Climate Change risk: an adaptation and mitigation agenda for Indian Cities. Environment and Urbanisation, 20(1),p. 207.

6. Roy J., India K., 2006. The Economics of Climate Change. A Review of Studies in the Context of South Asia with a Special Focus on India, Jadavpur University, Kolkata, India.

7. Sharma S., Bhattacharya S., 2006. Greenhouse Gas emissions in India: A Perspective.Current Science, 90(3),pp.326-333.

8. Siemens, A. G., 2011. Assessing the Environmental Performance of Asis's Major Cities, Munich. Asia Green City Index.

9. Tripathy M., Joshi H.,, 2015. Carbon Flow in Delhi Urban Forest Ecosystem. 14. Tripathy M., Joshi H., 2015, Carbon Flow in Delhi UrbanScholars Research Library,Annals of Biological Research,,6(8), pp. 13-17.

10. Winter, P. S., 1998. Green Growth: India Environment Challenge. Harward International Review,21(1), pp.68-71. 